\title{
CHARACTERIZATION OF GRAM-NEGATIVE BACTERIA ISOLATED FROM LUNGS OF CAMEL
}

\author{
* Amgad A. Moawad;** Hala S. Ibrahim and Marwa M. Elsherbiny \\ * Dept. of Bacteriology, Mycology and Immunology, Fac. Vet. Med., \\ Kafrelsheikh Univ., Egypt \\ ** Dept. of Microbiology, Animal Health Research institute, Dokki.,Giza, Egypt. \\ E-mail: amgadprof 2003@ hotmail.com
}

\begin{abstract}
Out of 308 samples 205 from apparently healthy and 103 diseased lung of slaughtered camels. The total number of positive samples was 203 (65.91\%) from which 124 (60.49\%) from apparently healthy and $79(76.70 \%)$ from pneumonic lung of camels.

The total number of isolates was 302 isolates from which 174 isolates from apparently healthy and 128 isolates from pneumonic lung of camels. The total number of Gram negative isolates 170 (56.29\%) from which isolates were 94 (54.02\%) and 76 (59.38\%) in apparently healthy and diseased lungs of camel respectively as shown in table (3).

On the other hand the main predominant single Gram negative isolates were E. coli 28 samples (26.92\%), Pseudomonas aeruginosa 9 samples (8.65\%), Citrobacter freundii 7 samples (6.73\%), Klebsiella pneumoniae 6 samples (5.77\%), Citrobacter spp. 5samples (4.81\%), Klebsiella oxytoca 3 samples (2.89\%), Mannheimia haemolytica and Yersinia enterocolitica 2 samples (1.92\%), Klebsiella ozaenae and Pasteurella multocida one sample (0.96\%).
\end{abstract}


Serological identification from apparently and pneumonic lung of slaughtered camels was 44 isolates of E. coli including 29 isolates from apparently healthy as E. coli $O_{111}$, E. coli $O_{115}$, E.coli $O_{119} E$. coli $O_{146}$ and E. coli $O_{166}$ and 20 isolates from pneumonic lung including E. coli $O_{55}$, E. coli $O_{111}$ E. coli $O_{115}$, E. coli $O_{119}$, E. coli $O_{125}$, E. coli $O_{146}$ and E. coli $O_{166}$.

Regarding to the pathogenicity of gram negative isolates in experimentally infected mice by $0.1 \mathrm{ml}\left(5 \times 10^{8} \mathrm{cFm} . \mathrm{ml}\right)$. It was fatal to mice with varying pathogenicity, Klebsiella pneumoniae, E. coli $O_{55}$, E. coli $O_{115}$, Pseudomonas aerouginosa, Pasteurella multocida and Mannheimia haemolytica were 100\%. Meanwhile the lowest pathogenic bacteria were E. coli $O_{119}$ and Proteus vulgaris were $20 \%$. But citrobacter spp. and Proteus penneri not causing deaths among mice.

Chloramphenicol, Ciprofloxacin, Enrofloxacin, Flumequine, Gentamicin and Norfloxacin against Citrobacter freundii, Citrobacter spp., E. coli, Enterobacter cloacae, K. oxytoca, K. ozaenae and $K$. pneumoniae. Ciprofloxacin, Doxycycline, Enrofloxacin and Norfloxacin against Mannheimia haemolytica, Pasteurella multocida, Proteus penneri, Proteus vulgaris, Ps. aeruginosa and Yersinia enterocolitica.

SDS-PAGE analysis of Klebsiellae and E. coli showed that they contained from 5 to 12 bands after staining with Commiassie brilliant blue method which molecular weight ranged from 7.218 to 170.97 $K D a$.

It was obvious that the molecular weight of $\mathrm{E}$. coli $\mathrm{O}_{55}$ ranged from 134.55 to $7.2118 \mathrm{KDa}$. The molecular weight of E. coli 111 ranged from 134.55 to $32.208 \mathrm{KDa}$. The molecular weight of E. coli $O_{115}$ 
ranged from 134.55 to $33.311 \mathrm{KDa}$. The molecular weight of E. coli $O_{119}$ ranged from 131.24 to $8.4471 \mathrm{KDa}$. The molecular weight of $\mathrm{E}$. coli $O_{125}$ ranged from 118 to $28.562 \mathrm{KDa}$. The molecular weight of $E$. coli $O_{146}$ ranged from 151.11 to $11.741 \mathrm{KDa}$. The molecular weight of E. coli $O_{166}$ ranged from 154.41 to 21.137 .

On the other hand the molecular weight of Klebsiella oxytoca ranged from 157.72 to $15.859 \mathrm{KDa}$. The molecular weight of Klebsiella pneumoniae ranged from 167.66 to $22.15 \mathrm{KDa}$. The molecular weight of Klebsiella ozaenae ranged from 170.97 to $38.016 \mathrm{KDa}$.

Key Words: Klebsiella, E coli, pneumonic lung, antimicrobial agents.

\section{INTRODUCTION}

Camel plays vital socioeconomic roles and supports the survival of millions of people in Asia and Africa. It is being used as a source of protein, milk and hides as well as quiet and effective means of transport (Chowdhary, 1986).

Respiratory affections are the main causes of death among camel calves all over the world (Chowdhary, 1986 and Khanna et al., 1992).

Bacterial infection of lung is one of the main causes of pneumonia (Thabet, 1994). Many gram negative bacteria were isolated from pneumonic lungs as pseudomonas spp., E. coli, Klebsiella spp., Mannheimia haemolytica, Pasteurella multocida, and Citrobacter spp. Thabet (1994), Amany (2000) and Azzam and Zaki (2006).

The whole cell protein profiles of bacteria can be easily studied on SDS-PAGE. This powerful technique allows very high resolution of protein and has permitted the identification of multiple major proteins components of different molecular weights. 
The present work was aimed to study the Gram-negative bacterial species of respiratory system of camels. For achieving the following points:

- Isolation and identification of gram negative bacteria recovered from apparently healthy and pneumonic lungs of camels.

- Serogrouping of isolated E. coli.

- Determination of the pathogenicity of isolates to mice.

- Detecting the antibiogram against the isolated bacteria.

- Studying the SDS-PAGE of whole cell proteins of some Klebsiellae and E. coli strains.

\section{MATERIAL AND METHODS}

\section{MATERIALS:}

\subsection{Samples for isolation:}

- 308 samples from imported slaughtered camels were collected from El-Basatein abattoir, Cairo-Egypt, The collected samples were 250 samples from apparently healthy and 102 samples had pathological lesions.

- All samples were kept in clean plastic ice bags in cooling container and transferred as soon as possible to the laboratory of Animal Health Research institute, Dokki, Egypt, for bacteriological examination.

\section{- 1.2. Media used for isolation and cultivation of bacteria:}

\section{- 1.2.1. Fluid media:}

- 1. 2.1.1. Nutrient broth: (Oxoid, Code CM1) 
1. 2.2. solid media:

- 1. 2.2.1. Nutrient agar medium: (Oxoid, Code, CM3)

- 1.2.2.2. Blood agar medium: (Oxoid, Code, CM55)

- 1.2.2.3. MacConkey lactose bile salt agar: (Oxoid, Code, CM115)

- 1.2.2.4. DAS medium: (Oxoid)

- 1.2.2.7. Eosin Methylene Blue agar (EMB agar): Quinn et al. (1994)

- 1.2.3. Semisolid media: (soft agar): (Cruickshank et al. 1975)

This medium was used for the preservation of all isolates.

1.3. Media used for biochemical identification of the isolates:

All media used were prepared according to Cruickshank et al. (1975) and Koneman et al. (1988).

- 1.3.1. Peptone water 1\%: (Oxoid, Code L37)

- 1.3.2. Glucose phosophate broth:(Oxoid, Code CM43)

- 1.3.3. Simmon's citrate agar: (Oxoid, CM115)

- 1.3.4. Urea agar base: (Oxoid, CM53)

- 1.3.5. Nutrient gelatin: (Oxoid, CM35a)

- 1.3.6. Nitrate broth: (Difco, 268)

- 1.3.7. Triple sugar iron agar medium (T.S.I): (Oxoid, Code M277)

- 1.3.8. Sugar fermentation media: (Kreig and Holt, 1984)

- 1.3.9. Phenyl alanine agar: (Cowan, 1979).

- 1.3.10. Amino acid decarboxylase test. 


\subsection{Stains used:}

- 1.4.1.Gram's stain:It was prepared according to Mackie and MacCarteny (1989).

- 1.4.2.Leishman stain: (Cruickshank et al.,1975)

1.5. Chemical and Reagents: It was prepared according to Koneman et al. (1988).

- 1.5.1. 3\% hydrogen peroxide for catalse test .

- 1.5.2. Tetra-methyl-p-phenylene diamine $1 \%$ for oxidase test.

- 1.5.3. Kovac's reagent: for the indole test.

- 1.5.4. $0.04 \%$ methyl red solution: for methyl red test.

- 1.5.5. Solution I of $5.0 \% \alpha$-naphthol in absolute ethyl alcohol and solution II of $40 \%$ potassium hydroxide solution for Voges Proskauer test.

- 1.5.6. $40 \%$ urea solution (Oxoid SR 20): for urease test.

- 1.5.7. Reagent I of $0.8 \%$ sulfanilic acid in $10 \mathrm{~N}$ acetic acid and reagent II of $0.5 \% \alpha$-naphthylamine in $5 \mathrm{~N}$ acetic acid for nitrate reduction test.

- 1.5.8. $10 \%$ and $40 \%$ bile salt.

- 1.5.9. $10 \%$ ferric chloride for phenyl alanine deaminase test.

- 1.5.10. Streile paraffin oil for Arginine dehydrolase test.

- 1.5.11. Phosophate buffer saline (Emery et al., 1992) for serogrouping of Escherichia coli. 
1.6. Diagnostic Escherichia coli antisera: The polyvalent and monovalent antisera used were:

- Polyvalent 1: Contain: $\mathrm{O}_{1}, \mathrm{O}_{26}, \mathrm{O}_{86 a}, \mathrm{O}_{111}, \mathrm{O}_{119}, \mathrm{O}_{127 a}, \mathrm{O}_{128}$,

- polyvalent 2: Contain: $\mathrm{O}_{44}, \mathrm{O}_{55}, \mathrm{O}_{125}, \mathrm{O}_{126}, \mathrm{O}_{146}, \mathrm{O}_{166}$,

- polyvalent 3: Contain: $\mathrm{O}_{18}, \mathrm{O}_{114}, \mathrm{O}_{142}, \mathrm{O}_{151}, \mathrm{O}_{157}, \mathrm{O}_{128}$

- polyvalent 4: Contain: $\mathrm{O}_{6}, \mathrm{O}_{27}, \mathrm{O}_{78}, \mathrm{O}_{148}, \mathrm{O}_{159}, \mathrm{O}_{168}$

- Polyvalent 5: Contain: $\mathrm{O}_{20}, \mathrm{O}_{25}, \mathrm{O}_{63}, \mathrm{O}_{153}, \mathrm{P}_{167}$

- polyvalent 6: Contain: $\mathrm{O}_{8}, \mathrm{O}_{15}, \mathrm{O}_{115}, \mathrm{O}_{169}$

- polyvalent 7: Contain: $\mathrm{O}_{28 a c}, \mathrm{O}_{112 a c}, \mathrm{O}_{124}, \mathrm{O}_{136}, \mathrm{O}_{144}$ and

- polyvalent 8: Contain: $\mathrm{O}_{29}, \mathrm{O}_{143}, \mathrm{O}_{152}, \mathrm{O}_{164}$

It was obtained from Denka Seiken Co., LTD 3-4-2 Nihonbashikayaba - , Chuo. Ju, Tokyo, Japan.

\subsection{Laboratory animals:}

\section{White mice:}

Swiss Webster white mice weighting 18 - 22 grams were used to measure the virulence of bacterial isolates.

\subsection{Diagnostic antibiotics and chemotherapeutic agents: (Oxoid):}

Antimicrobial sensitivity discs were obtained from Oxoid. The sensitivity of bacterial isolates was tested against the following antimicrobial agent's disks: ciprofloxacin. $(3 \mu \mathrm{g})$, cloxacillin $(5 \mu \mathrm{g})$, chloramphenicol $(30 \mu \mathrm{g})$, Doxycyline $(30 \mu \mathrm{g})$, enrofloxacin $(5 \mu \mathrm{g})$, flumequine $(30 \mu \mathrm{g})$, Gentamicin $(10 \mu \mathrm{g})$, norfloxacin $(10 \mu \mathrm{g})$, penicillin $(10 \mu \mathrm{g})$, streptomycin $(10 \mu \mathrm{g})$ and trimethoprim $(5 \mu \mathrm{g})$. 
1.9. Sodium Dodecyl Sulphate Polyacrylamide Gel Electrophoresis (SDS-PAGE):

Determination of whole cell protein the molecular weight of the (Klebsiella spp. and E. coli serogrouping) by the SDS-PAGE according to (Laemmli, 1970).

\section{i- Equipment:}

1-Mini-protean 3 electrophoresis (Bio Rad).

2-Power supply.

\section{ii-Reagents:}

1- Acrylamide $30 \%$ stock solution : Stored in $4{ }^{\circ} \mathrm{C}$. In brown bottle.

2- Separation buffer: PH adjusted to 8.8 with $6 \mathrm{~N} \mathrm{HCL}$, Stored in 4 ${ }^{\circ} \mathrm{C}$. In brown bottle.

3- Stacking buffer: $\quad \mathrm{PH}$ adjusted to 6.8 with $6 \mathrm{~N} \mathrm{HCL}$, stored in $4 \mathrm{C}^{0}$. in brown bottle.

4- Ammonium persulphate (APS): $400 \mu \mathrm{g} / \mathrm{ml}$ (stored at- $20 \mathrm{C}^{0}$ in small aliqutes).

5- TEMED (NNN'N' tetramethyl ethylene diamine).

6- Glycerol pure $100 \%$.

7- Sample buffer (2x).

$\mathrm{PH}$ adjusted to 6.8 , Stored at $4 \mathrm{C}^{0}$ in brown bottle.

8- Stock electrophoresis (10x).

9- Commassie blue stain: $(0.25 \%$ commassie blue powder dissolved in destaining solution). 
10- De-staining solution: $45 \%$ methanol. $50 \%$ glacial acetic acid and $50 \%$ distilled water.

11- Matrix contains $10 \%$ separating gel.

\section{METHODS:}

\subsection{Collection and preparation of samples:}

Samples were obtained from apparently healthy and diseased lungs which showing various macroscopic pathological changes pneumonia. The samples were collected separately in sterile plastic ice bags and transported immediately to the laboratory in ice box for bacteriological examination.

\subsection{Bacteriological examination:}

\subsubsection{Cultivation:}

The surface was sterilized by hot spatula then opened by sterile scalpel. Sterile platinum loop was inserted inside the opening then inserted into nutrient broth also one gm from sample was put in $10 \mathrm{ml}$ of nutrient broth and incubated aerobically at $37^{\circ} \mathrm{C}$ for $24 \mathrm{hrs}$. The suspected colonies were picked up and subculture into nutrient agar and specific media plates for each bacteria to confirm their purity then into nutrient agar slopes for identification.

\subsubsection{Identification of bacterial isolates (Fineglod and Martin, 1982 and Quinn et al., 1994):}

Cultivated plates were examined after $24-48 \mathrm{hrs}$ incubation at $37^{\circ} \mathrm{C}$ for any bacterial growth. Colonies were identified according to: 


\subsubsection{Culture characters:}

The cultural characteristic of each purified isolate were studied on solid madia according to their shape, size ,elevation ,structure of surface, colour, pigment and type of haemolysis .

\subsubsection{Microscopical examination:}

The isolated organisms were classified according to shape, size, arrangement and gram staining reaction into: Gram positive cocci, Gram positive non spore forming rods and Gram negative rods.

\subsubsection{Biochemical identification:}

\subsection{Identification of Gram negative rods (Quinn et al., 2002):}

\subsection{Identification of Pseudomonas species.}

Pyocyanine production (pigment production), Oxidase production, Gelatin liquefaction, Growth at $4^{\circ} \mathrm{C}$ and $41^{\circ} \mathrm{C}$, Catalase test, Reduction of nitrate, Decarboxylation of arginine (Arginine dihydrolase) and sugar utilization test.

\subsection{Differentiation of members of Family Enterobacteriaceae:}

Indole production, Methyl red, Voges proskauer, Citrate utilization, Urease activity, Hydrogen sulphide production, Motility and swarming on blood agar, Gelatin liquefaction. and Sugar fermentation test.

\subsection{Differentiation of Pasteurella spp. (Barrow and Feltham, 1993):}

Motility, Catalse test, Oxidase test, Growth on the MacConkey agar plates, Sugar fermentation test using arabinose, lactose, maltose, mannitol, raffinose, salicin, sorbitol, sucrose and trehalose, Aesculin hydrolysis, Nitrate reduction test, Indole production test, Gelatin hydrolysis, Urease hydrolysis test and $\mathrm{H}_{2} \mathrm{~S}$ production by using lead acetate paper. 


\subsection{Serological identification:}

\subsubsection{Serogrouping of Escherichia coli isolates: (Edwards and Ewing, 1972).}

All the suspected microorganisms were subjected to serological typing by slide agglutination test using standard polyvalent and monovalent E. coli antisera. Only fresh bacterial cultures $24 \mathrm{hrs}$ colonies onto nutrient agar medium were used and not from the selective medium.

\section{Slide agglutination test:}

When a colony gave a strongly positive agglutination with one of the pools of polyvalent serum, a further portion of it was inoculated into a nutrient agar slant and incubated to grow as a culture to test with monovalent sera.

\subsection{Pathogenicity test of bacterial isolates in mice:}

\section{a) Preparation of bacterial suspension: (Stamp et al. 1959).}

The bacterial suspension was made by plate washing technique. From the original culture, this was plated onto $10 \%$ sheep blood agar plate and then incubated for $24 \mathrm{hrs}$ at $37^{\circ} \mathrm{C}$. The inoculated plate was flooded with $5 \mathrm{ml}$ saline and the colonies were removed from the solid medium by gentle rubbing with a glass rod, the resultant suspension were adjusted to be contained on average of $3 \times 10^{8}$ colony forming unite (CFU) per ml (adjusted to match a McFarland standard tube No.1).

\section{b) Route of injection (Wessman, 1964):}

Five mice were used for each isolate; they were injected from the prepared solution using sterile disposable plastic syringes. Each mouse was given $0.1 \mathrm{ml}$ of bacterial suspension $\mathrm{I} / \mathrm{P}$ in the group for the detection of pathogencity.The mortalities rates and the pathogencity rate were calculated. 
2.5. Susceptibility of the isolated strains to various antimicrobial agents:

The disk diffusion technique was adapted according to Fineglod and Martin (1982).

\subsubsection{Preparation of the standardized inoculums:}

- Four or five typical colonies of similar morphology were transferred using a sterile loop to a tube containing $5 \mathrm{ml}$ of sterile Mueller Hinton broth.

- The broth was incubated at $37^{\circ} \mathrm{C}$ for $2-8 \mathrm{hrs}$ for its turbidity exceeds that of the standard McFerland tube 0.5 barium sulphate tube $(0.5 \mathrm{ml}$ of $1.175 \%$ barium chloride hydrate to $99.5 \mathrm{ml}$ of $1 \%$ sulphuric acid). The turbidity was adjusted to match a McFerland 0.5 barium sulphate standard tube by adding sterile saline using adequate light

\subsubsection{Inoculation of the tested plates:}

- A sterile cotton swab was dipped into the standardized bacterial suspension.

- Excess fluid was removed by rotating the swab with firm pressure against the inside wall of the tube above the fluid level.

- The swab was then used to streak the dried surface of MullerHinton agar plate in three different planes by rotating the plate approximately (60) degree each time to ensure an even distribution of the inoculation.

- The plate lids were placed and the inoculated plates were allowed to remain on a flat level surface undistributed for 3 to 5 minutes to allow the adsorption of excess moisture then the disks were applied. 


\subsubsection{Application of chemotherapeutic discs:}

- With fine-pointed forceps, the selected antimicrobial discs were placed onto the inoculated plates.

- The discs were distributed evenly in a manner such as to be no closer than $15 \mathrm{~mm}$ from the edge of Petri dish and so that no two discs were closer than $24 \mathrm{~mm}$ from center to center.The plates were then incubated at $37^{\circ} \mathrm{C}$ for $24 \mathrm{hrs}$.

\subsubsection{Interpretation of the zone of inhibition:}

By measuring clear zone of inhibition of growth produced by diffusion from the discs into the surrounding medium.according to the Koneman et al. (1983) and Oxoid Manual (1982) Table (2).

Table (2): Interpretation of zones of inhibition for antibacterial susceptibility.

\begin{tabular}{|c|c|c|c|c|}
\hline \multirow{2}{*}{$\begin{array}{c}\text { Antibiotics and chemo } \\
\text { therapeutic agents }\end{array}$} & \multirow{2}{*}{ Symbol } & \multirow{2}{*}{ Conc. in $\mu \mathrm{g}$} & \multicolumn{2}{|c|}{ Diameter of inhibition zone } \\
\hline & & & Sensitive & Resistance \\
\hline Chloramphenicol & $\overline{\mathrm{CC}}$ & 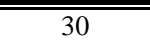 & $=18$ & $\overline{s \leq 12}$ \\
\hline Ciprofloxacin & Cip & 5 & $\geq 21$ & $\leq 15$ \\
\hline Cloxacillin & OB & 5 & $\geq 18$ & $\leq 14$ \\
\hline Doxycycline & Do & 30 & $19-23$ & $15-18$ \\
\hline Enrofloxacin & Enr & 5 & $\geq 18$ & $\leq 14$ \\
\hline Flumequine & $\overline{U B}$ & 30 & $\geq 16$ & $\leq 13$ \\
\hline Gentamicin & $\mathrm{CN}$ & 10 & $\geq 15$ & $\leq 12$ \\
\hline Norfloxacin & Nor & 10 & $\geq 17$ & $\leq 12$ \\
\hline Pencillin G & $\mathrm{P}$ & 10 & $\geq 19$ & $\leq 14$ \\
\hline Streptomycin & $\mathrm{S}$ & 10 & $\geq 15$ & $\leq 11$ \\
\hline Trimethoprim & $\mathrm{Tr}$ & 5 & $\geq 16$ & $\leq 10$ \\
\hline
\end{tabular}

All obtained from Oxoid Company

\subsection{Sodium Dodecyl Sulphate Polyacrylamide Gel Electrophoresis (SDS-PAGE):}

It was performed according to the method described by Laemmli (1970). 


\subsubsection{Casting of the gel:}

1. Fifteen $\mathrm{ml}$ of $12 \%$ gel was prepared and the polymerization process occurred as soon as temed was added then poured in between the two glass plates carefully to avoid air bubbles.

2. Leaving a sufficient space for stacking gel.

3. After polymerization was completed (30 minutes.), the top of the gel was washed by deionized water for several times to remove non polymerized solution then removal of any water by using towel paper.

4. The stacking gel was prepared and then poured directly on the surface of polymerized separating gel.

5. A clean Teflon comp was immediately inserted into the stacking gel solution careful to avoid trapping any air bubbles. The gel was kept in a vertical position at room temperature till polymerization.

\subsubsection{Preparation of the samples:}

The samples $10 \mu \mathrm{l} /$ well was treated with the reducing buffer in ratio of 1:2 the treated samples were immersed in a boiling water for 2 minutes to insure protein denaturation.

\subsubsection{Samples loading:}

1. After polymerization of stacking gel was completed the Teflon comp was carefully removed and the formed wells washed by deionized water to remove any of the non polymerized solution.

2. The gel was mounted in the tank of electrophoresis apparatus. The running buffer was added to the top and bottom reservoirs and removal of any air bubbles was assured.

3. About, $10 \mu \mathrm{l}$ of each sample and marker were loaded with its loading buffer into wells of the gel. The power supply was turned on and the current was adjusted at 2 minutes Amp/sample and the voltage was adjusted at 100 volt. 
4. The power supply was turned off when the blue line descends to the bottom of the rubber of the electrophoresis apparatus.

\subsubsection{Commassie brilliant blue (R-250) 0.25: (Laemmli, 1970).}

The gel was removed between the two glass blades carefully and placed in staining (Commassie brilliant blue) followed by gentle shaking (20 minutes.) and washed gently with deionized water.

The gel removed from deionized water and placed in destained solution (45\% methanol, 50\% glacial acetic acid and 50\% distilled water) for 30-45 minutes.

Destaining was carried out several times until bands appeared and the gel cleared.

\section{RESULTS}

\subsection{Incidences and types of positive cases yielded single or mixed bacterial isolates from lungs of slaughtered camels:}

Table (3): The incidences and types of positive cases yielded single or mixed bacterial isolates from lungs of slaughtered camels.

\begin{tabular}{|c|c|c|c|c|c|c|c|c|c|c|c|c|}
\hline 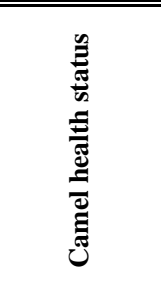 & 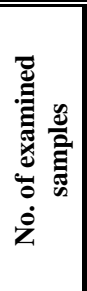 & 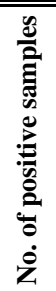 & $\%^{*}$ & 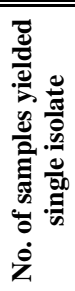 & $\%^{* *}$ & 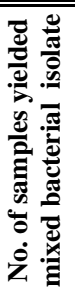 & $\%^{* *}$ & 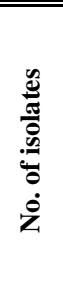 & 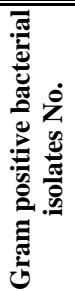 & $\%^{* * * *}$ & 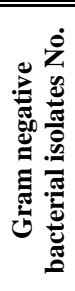 & $\%^{* * * *}$ \\
\hline $\begin{array}{l}\text { Apparently } \\
\text { healthy }\end{array}$ & 205 & 124 & 60.49 & 74 & 59.68 & 50 & 40.32 & 174 & 80 & 45.98 & 94 & 54.02 \\
\hline $\begin{array}{c}\text { Diseased } \\
\text { (pneumonic) }\end{array}$ & 103 & 79 & 76.70 & 30 & 37.97 & 49 & 62.03 & 128 & 52 & 40.63 & 76 & 59.38 \\
\hline Total & 308 & 203 & 65.91 & 104 & 51.23 & 99 & 48.77 & 302 & 132 & 43.71 & 170 & 56.29 \\
\hline
\end{tabular}

* The percentage was calculated according to number of examined samples of each camel health status.

** Percentage was calculated according to total No. of positive samples of each camel health status.

*** Percentage was calculated according total number of isolates (174) from apparently healthy and (128) from pneumonic camel lungs. 
Amgad A. Moawad et., al.

Table (4): The incidences and types of bacterial isolates recovered from apparently healthy and pneumonic lungs of slaughtered camels.

\begin{tabular}{|c|c|c|c|c|}
\hline \multirow{2}{*}{ Types of bacteria } & \multicolumn{2}{|c|}{ Apparently healthy lungs (124 samples) } & \multicolumn{2}{|c|}{ Pneumonic lungs (79 samples) } \\
\hline & No. of isolates & $\%{ }^{*}$ & No. of isolates & $\%^{*}$ \\
\hline \multicolumn{5}{|l|}{ b) Gram negative isolates } \\
\hline Citrobacter freundii & 11 & 6.32 & 5 & 3.91 \\
\hline Citrobacter spp. & 8 & 4.6 & 3 & 2.34 \\
\hline E. coli & 29 & 16.67 & 20 & 15.63 \\
\hline Enterobacter cloacae & 7 & 4.02 & 3 & 2.34 \\
\hline Klebsiella oxytoca & 8 & 4.60 & 6 & 4.69 \\
\hline Klebsiella ozaenae & 3 & 1.72 & 2 & 1.56 \\
\hline Klebsiella pneumoniae & 0 & 0 & 12 & 9.38 \\
\hline Pseudomonas aeruginosa & 6 & 3.45 & 10 & 7.81 \\
\hline Mannheimia haemolytica & 0 & 0 & 2 & 1.56 \\
\hline Pasteurella multocida & 0 & 0 & 1 & 0.78 \\
\hline Proteus penneri & 9 & 5.17 & 4 & 3.13 \\
\hline Proteus vulgaris & 5 & 2.87 & 2 & 1.56 \\
\hline Yersinia enterocolitica & 8 & 4.6 & 6 & 4.69 \\
\hline Total & 94 & 54.02 & $\overline{76}$ & 59.38 \\
\hline
\end{tabular}

N.B: Total number of bacterial isolates from apparently healthy lung were 171 including gram positive \&gram negative ones while total number of bacterial isolates from pneumonic lungs were 128 including also gram positive \& and gram negative bacteria.

*The percentage was calculated according to the total number of bacterial isolates from each camel health status.

Table (5): The incidences and types of single isolated gram negative isolate recovered from both apparently healthy and pneumonic lungs of slaughtered camels.

\begin{tabular}{|c|c|c|c|c|c|c|}
\hline \multirow[t]{2}{*}{ Isolated microorganisms } & \multicolumn{2}{|c|}{$\begin{array}{c}\text { Total positive samples } \\
\text { from lungs }\end{array}$} & \multicolumn{2}{|c|}{$\begin{array}{c}\text { Positive samples from } \\
\text { apparently healthy lungs }\end{array}$} & \multicolumn{2}{|c|}{$\begin{array}{c}\text { Positive samples from } \\
\text { pneumonic lungs }\end{array}$} \\
\hline & No. & $\% *$ & No. & $\%$ & No. & $\%$ \\
\hline \multicolumn{7}{|l|}{ b) Gram negative isolates } \\
\hline Citrobacter freundii & 7 & 6.73 & 7 & 9.46 & 0 & 0 \\
\hline Citrobacter spp. & 5 & 4.81 & 5 & 6.76 & 0 & 0 \\
\hline E. coli & 28 & 26.92 & 21 & 28.38 & 7 & 23.33 \\
\hline Klebsiella oxytoca & 3 & 2.89 & 3 & 4.05 & 0 & 0 \\
\hline Klebsiella ozaenae & 1 & 0.96 & 1 & 1.35 & 0 & 0 \\
\hline Klebsiella pneumonia & 6 & 5.77 & 0 & 0 & 6 & 20 \\
\hline Mannheimia haemolytica & 2 & 1.92 & 0 & 0 & 2 & 6.67 \\
\hline Pasteurella multocida & 1 & 0.96 & 0 & 0 & 1 & 3.33 \\
\hline Pseudomonas aeruginosa & 9 & 8.65 & 4 & 5.41 & 5 & 16.67 \\
\hline Yersinia enterocolitica & 2 & 1.92 & 2 & 2.7 & 0 & 0 \\
\hline Total & 104 & 100 & 74 & 71.15 & 30 & 28.85 \\
\hline
\end{tabular}

* The percentage was calculated according to the total number of positive samples(104) in all lung samples, (74) in apparently healthy lungs and (30) in pueumonic lungs.

$\overline{\text { Kafrelsheikh Vet. Med. J. Vol. } 9 \text { No. } 1 \text { (2011) }}$ 
Characterization Of Gram-Negative Bacteria Isolated From ...

Table (6): The incidences and types of mixed bacterial isolates recovered from both apparently healthy and pneumonic lungs of slaughtered camels.

\begin{tabular}{|c|c|c|c|c|c|c|}
\hline \multirow[t]{2}{*}{ Isolated microorganisms } & \multicolumn{2}{|c|}{$\begin{array}{c}\text { Total positive } \\
\text { samples from lungs } \\
\end{array}$} & \multicolumn{2}{|c|}{$\begin{array}{c}\text { positive samples from } \\
\text { apparently healthy lungs }\end{array}$} & \multicolumn{2}{|c|}{$\begin{array}{c}\text { positive samples from } \\
\text { pneumonic lungs }\end{array}$} \\
\hline & No. & $\%$ & No. & $\%$ & No. & $\% *$ \\
\hline $\begin{array}{l}\text { A.rcanobacterium pyogenes }+ \\
\text { Citrobacter spp. }\end{array}$ & 3 & 3.03 & 0 & 0 & 3 & 6.12 \\
\hline $\begin{array}{l}\text { C.itrobacter freundii }+ \\
\text { Yersinia. enterocolitica }\end{array}$ & 9 & 9.1 & 4 & 8 & 5 & 10.2 \\
\hline $\begin{array}{l}\text { Diplococcus pneumoniae }+ \\
\text { E. coli }\end{array}$ & 2 & 2.02 & 0 & 0 & 2 & 4.09 \\
\hline $\begin{array}{l}\text { Diplococcus. pneumoniae }+ \\
\text { Pseudomonas aeruginosa }\end{array}$ & 4 & 4.04 & 0 & 0 & 4 & 8.16 \\
\hline $\begin{array}{l}\text { Klebsiella oxytoca }+ \\
\text { E. coli }\end{array}$ & 3 & 3.03 & 0 & 0 & 3 & 6.12 \\
\hline $\begin{array}{l}\text { Klebsiella ozaenae }+ \\
\text { E. coli }\end{array}$ & 1 & 1.01 & 0 & 0 & 1 & 2.04 \\
\hline $\begin{array}{l}\text { Klebsiella ozaenae }+ \\
Y . \text { enterocolitica }\end{array}$ & 3 & 3.03 & 2 & 4 & 1 & 2.04 \\
\hline $\begin{array}{l}\text { Micrococcus spp.+ Citrobacter } \\
\text { spp. }\end{array}$ & 3 & 3.03 & 3 & 6 & 0 & 0 \\
\hline Micrococcus spp. + E. coli & 4 & 4.04 & 2 & 4 & 2 & 4.09 \\
\hline $\begin{array}{l}\text { Micrococcus spp. }+K . \\
\text { pneumoniae }\end{array}$ & 1 & 1.01 & 0 & 0 & 1 & 2.04 \\
\hline $\begin{array}{l}\text { Non hemolytic Streptococci + } \\
\text { Proteus vulgaris }\end{array}$ & 5 & 5.05 & 3 & 6 & 2 & 4.09 \\
\hline $\begin{array}{l}\text { Proteus penneri }+ \\
\text { Micrococcus spp. }\end{array}$ & 13 & 13.13 & 9 & 18 & 4 & 8.16 \\
\hline $\begin{array}{l}\text { Pseudomonas aeruginosa }+ \\
\text { E. coli }\end{array}$ & 1 & 1.01 & 0 & 0 & 1 & 2.04 \\
\hline $\begin{array}{l}\text { Pseudomonas aerugnosia }+ \\
\text { Proteus vulgaris }\end{array}$ & 2 & 2.02 & 2 & 4 & 0 & 0 \\
\hline $\begin{array}{l}\text { Staphylococcus aureus }+ \\
\text { D. pneumoniae }\end{array}$ & 2 & 2.02 & 0 & 0 & 2 & 4.09 \\
\hline $\begin{array}{l}\text { Staphylococcus aureus }+ \\
\text { E. coli }\end{array}$ & 10 & 10.10 & 6 & 12 & 4 & 8.16 \\
\hline $\begin{array}{l}\text { Staphylococcus aureus }+ \\
\text { E. cloacae }\end{array}$ & 10 & 10.10 & 7 & 14 & 3 & 6.12 \\
\hline $\begin{array}{l}\text { Staphylococcus aureus }+ \\
\text { K. oxytoca }\end{array}$ & 8 & 8.08 & 5 & 10 & 3 & 6.12 \\
\hline $\begin{array}{l}\text { Staphylococcus aureus }+ \\
\text { K. pneumoniae }\end{array}$ & 5 & 5.05 & 0 & 0 & 5 & 10.2 \\
\hline $\begin{array}{l}\text { Staphylococcus. aureus }+ \\
\text { non hemolytic Streptococci }\end{array}$ & 10 & 10.10 & 7 & 14 & 3 & 6.12 \\
\hline Total & 99 & 100 & 50 & 50.5 & 49 & 49.5 \\
\hline
\end{tabular}

*The Percentage was calculated according to the total number of positive samples (99) in all lungs samples, (50) in apparently lungs and (49) in pneumonic lungs.

Kafrelsheikh Vet. Med. J. Vol. 9 No. 1 (2011) 
Amgad A. Moawad et., al.

Table (7): Serogrouping of E. coli isolates from apparently healthy and pneumonic lungs of camels.

\begin{tabular}{|c|c|c|c|c|c|}
\hline \multicolumn{3}{|c|}{ Apparently healthy lungs } & \multicolumn{3}{|c|}{ Pneumonic lungs } \\
\hline Strain & No. of isolates & $\% *$ & Strain & No. of isolates & $\% *$ \\
\hline $\mathrm{O}_{111}$ & 6 & 20.68 & $\mathrm{O}_{111}$ & 2 & 10 \\
\hline $\mathrm{O}_{125}$ & 5 & 17.24 & $\mathrm{O}_{125}$ & 3 & 15 \\
\hline $\mathrm{O}_{166}$ & 5 & 17.24 & $\mathrm{O}_{166}$ & 4 & 20 \\
\hline $\mathrm{O}_{146}$ & 4 & 13.79 & $\mathrm{O}_{146}$ & 2 & 10 \\
\hline $\mathrm{O}_{55}$ & 3 & 10.35 & $\mathrm{O}_{55}$ & 5 & 25 \\
\hline $\mathrm{O}_{115}$ & 3 & 10.35 & $\mathrm{O}_{115}$ & 1 & 5 \\
\hline $\mathrm{O}_{119}$ & 3 & 10.35 & $\mathrm{O}_{119}$ & 3 & 15 \\
\hline Total & 29 & 100 & Total & 20 & 100 \\
\hline
\end{tabular}

*The Percentage was calculated according to number of isolates of each camel health status.

Table (9): Pathogenicity test of Gram negative bacterial isolates recovered from lungs of slaughtered camels.

\begin{tabular}{|c|c|c|c|c|c|c|c|c|c|}
\hline \multirow{2}{*}{ Examined bacteria } & \multicolumn{7}{|c|}{ No. of died mice/ day } & \multirow{2}{*}{ Total } & \multirow{2}{*}{$\% *$} \\
\hline & 1 & 2 & 3 & 4 & $\overline{5}$ & 6 & 7 & & \\
\hline 1.E. coli $\mathrm{O}_{55}$ & 3 & 2 & 0 & 0 & $\overline{0}$ & 0 & 0 & $5 / 5$ & $100 \%$ \\
\hline 2.E. coli $\mathrm{O}_{115}$ & 2 & 1 & 2 & 0 & 0 & 0 & 0 & $5 / 5$ & $100 \%$ \\
\hline 3.Klebsiella pneumoniae & 0 & 2 & 1 & 1 & 1 & 0 & 0 & $5 / 5$ & $100 \%$ \\
\hline 4.Mannheimia haemolytica & 4 & 1 & 0 & 0 & 0 & 0 & 0 & $5 / 5$ & $100 \%$ \\
\hline 5.Pasteurella multocida & 5 & 0 & 0 & 0 & 0 & 0 & 0 & $5 / 5$ & $100 \%$ \\
\hline 6.Pseudomonas aeruginosa & 1 & 2 & 2 & 0 & 0 & 0 & 0 & $5 / 5$ & $100 \%$ \\
\hline 7.E. coli $\mathrm{O}_{125}$ & 0 & 1 & 2 & 0 & 0 & 0 & 0 & $3 / 5$ & $60 \%$ \\
\hline 8.E. coli $\mathrm{O}_{146}$ & 2 & 1 & 0 & 0 & 0 & 0 & 0 & $3 / 5$ & $60 \%$ \\
\hline 9.E. coli $\mathrm{O}_{166}$ & 1 & 2 & 0 & 0 & 0 & 0 & 0 & $3 / 5$ & $60 \%$ \\
\hline 10.Citrobacter freundii & 0 & 0 & 1 & 1 & 0 & 0 & 0 & $2 / 5$ & $40 \%$ \\
\hline 11.E. coli $\mathrm{O}_{111}$ & 1 & 0 & 0 & 0 & 1 & 0 & 0 & $2 / 5$ & $40 \%$ \\
\hline 12.Enterobacter cloacae & 0 & 0 & 1 & 1 & 0 & 0 & 0 & $2 / 5$ & $40 \%$ \\
\hline 13.Klebsiella oxytoca & 0 & 0 & 1 & 1 & 0 & 0 & 0 & $2 / 5$ & $40 \%$ \\
\hline 14. Klebsiella ozaenae & 0 & 0 & 1 & 1 & 0 & 0 & 0 & $2 / 5$ & $40 \%$ \\
\hline 15.Yersinia enterocolitica & 0 & 1 & 1 & 0 & 0 & 0 & 0 & $2 / 5$ & $40 \%$ \\
\hline 16.E. coli $\mathrm{O}_{119}$ & 0 & 1 & 0 & 0 & 0 & 0 & 0 & $1 / 5$ & $20 \%$ \\
\hline 17.Proteus vulgaris & 0 & 0 & 1 & 0 & 0 & 0 & 0 & $1 / 5$ & $20 \%$ \\
\hline 18.Citrobacter spp. & 0 & 0 & 0 & 0 & 0 & 0 & 0 & 0 & $0 \%$ \\
\hline 19.Proteus penneri & 0 & 0 & 0 & 0 & 0 & 0 & 0 & 0 & $0 \%$ \\
\hline
\end{tabular}

*The percentage was calculated according to the number of examined mice of each strain

$\overline{\text { Kafrelsheikh Vet. Med. J. Vol. } 9 \text { No. } 1 \text { (2011) }}$ 
Table (11): The antibiotic and chemotherapeutic agents of Gram negative bacterial isolates recovered from apparently healthy and pneumonic lungs of slaughtered camels.

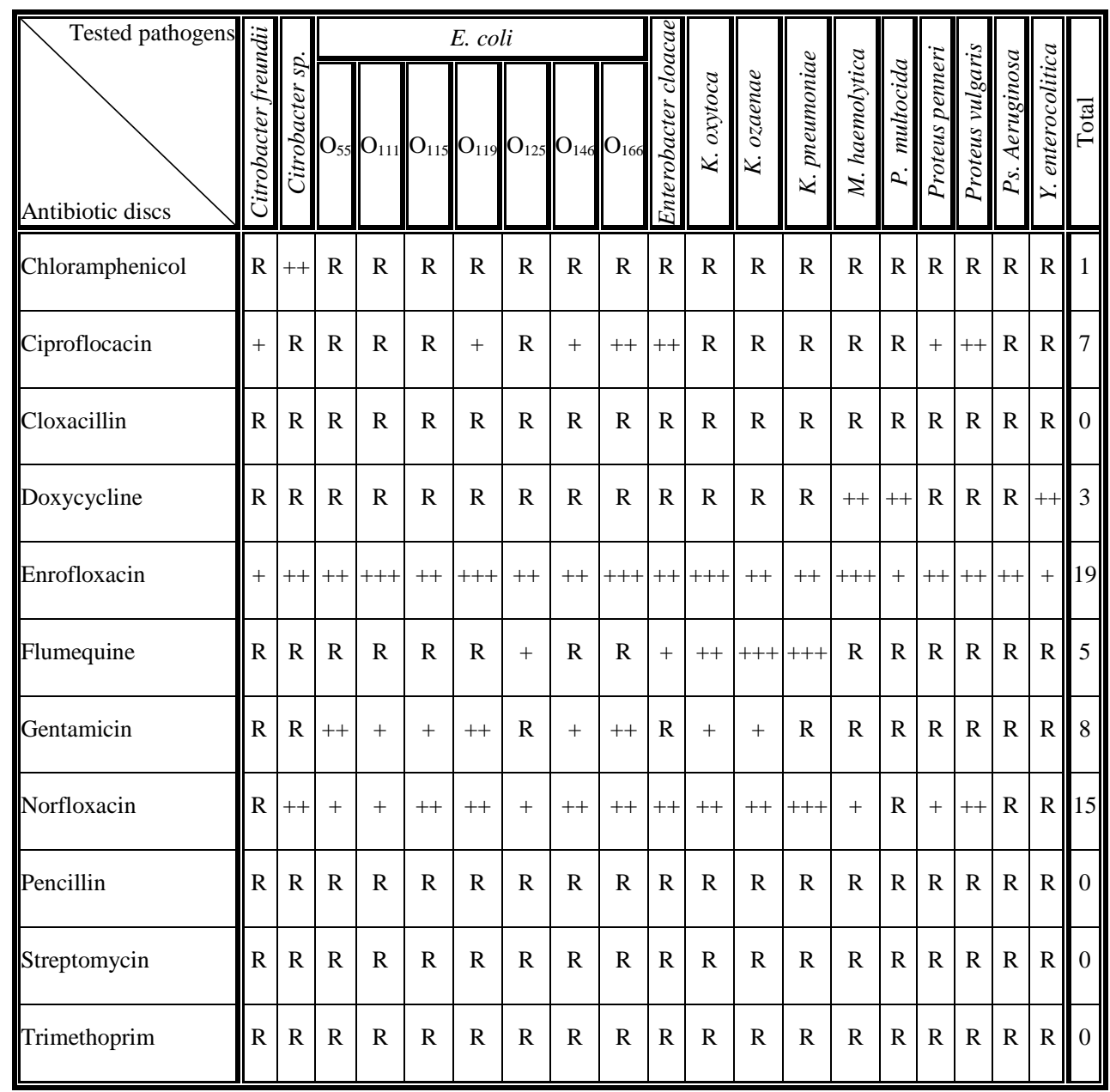

$-\mathrm{R}=$ Resistant

$-+=$ Sensitive $-++=$ Wide Sensitive zone

$-+++=$ Very wide Sensitive zone

Ten strains including 3 Klebsiellae :Klebsiella pneumoniae, Klebsiella oxytoca, Klebsiella ozaenae and 7 strains of E. coli including : E. coli $\mathrm{O} 55$, E. coli $\mathrm{O} 111$, E. coli $\mathrm{O} 115$, E. coli $\mathrm{O} 119$, E. coli $\mathrm{O} 125$, E. coli $\mathrm{O} 146$ and $E$. coli $\mathrm{O} 166$ isolated from camel lung samples. 
Amgad A. Moawad et., al.

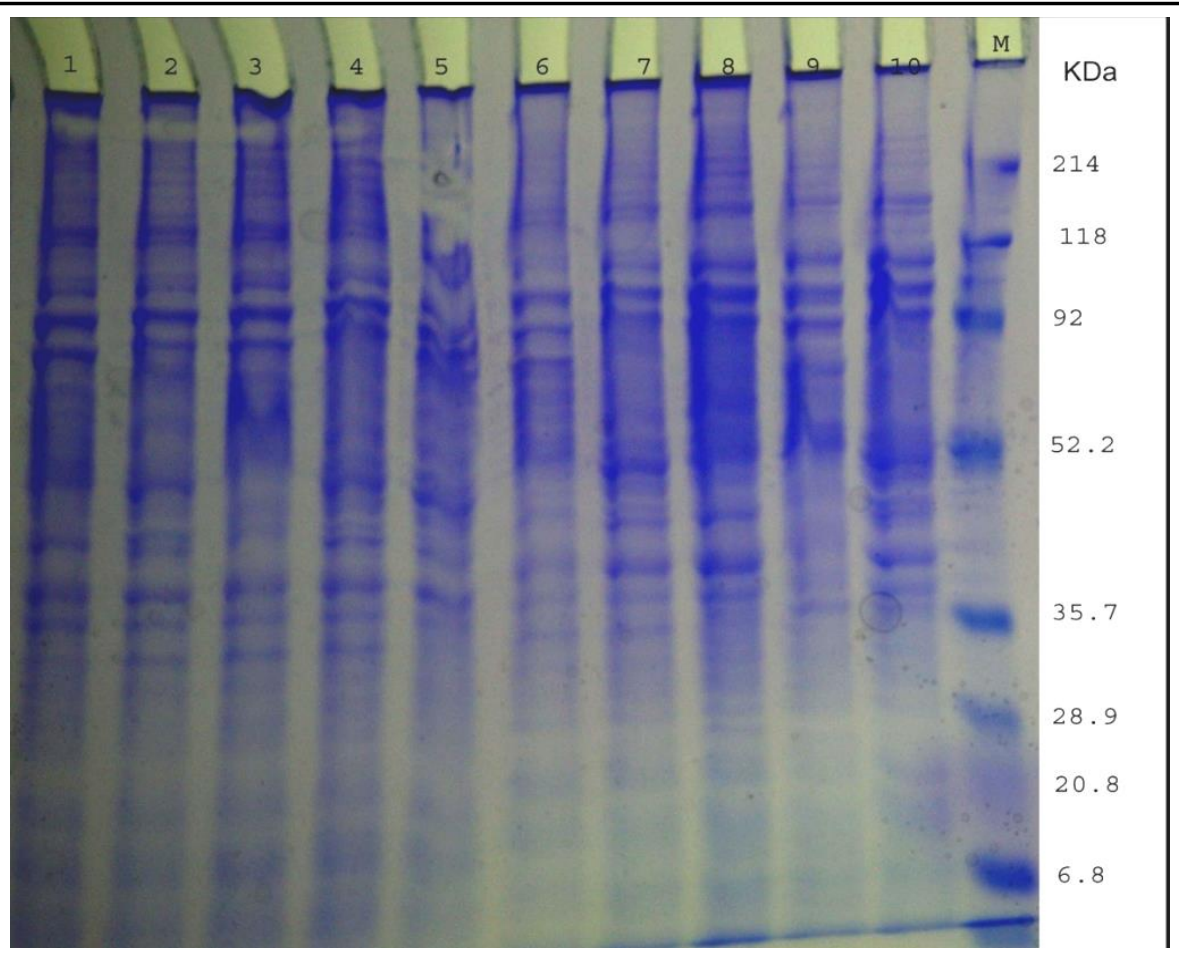

Photo (1): whole cell protein mixture were run on poly acrylamide gel stained with Commassie brilliant blue for detection of whole cell protein profiles lane 1 E. coli O55, lane 2 E. coli O111, lane 3 E. coli O115, lane 4 E. coli O119, lane 5 E. coli O125, lane 6 E. coli O146, lane 7 E. coli O166, lane 8 Klebsiella oxytoca, lane 9 Klebsiella pneumoniae and lane 10 Klebsiella ozaenae and lane 11, molecular weight marker Bio-Rad (214-118- 92- 52.2- 35.728.9- 20.8- $6.8 \mathrm{KDa})$.

\section{DISCUSSION}

Bacterial infection of the lungs is one of the main causes of pneumonia in camels (Rana et al., 1993; Thabet, 1994; Alhendi, 2000 and Seddek, 2002). 
The present study is a trial to find the pathogenic bacteria that are associated with camel's lungs, also to study the pathogenicity and antibacterial sensitivity of the bacterial isolates to control bacterial pneumonia in camels.

Several hygienic factors may be predisposing causes of respiratory disease. These including long period without food, keeping in dirty stalls Baba et al., 1994) and transportation as camels come yearly from North of Sudan to south of Egypt and collected then remained for several weeks in daraw quarantine, Aswan, Egypt . Cold, raining and dust during winter are predisposing factors for respiratory infection (Ning et al. 1998).

As clear from Table (5) that bacteriological examination of 308 camel lung samples (205 apparently healthy and 103 pneumonic) revealed that 203 samples were bacteriologically positive with an incidence of $65.91 \%$. These result was similar to that reported by Mahmoud et al. (1988) who found that $67.3 \%$ of lung samples were bacteriologically positive but Lower incidences were recorded by Ebtesam et al. (2009) and Moustafa (2004) who obtained $47.06 \%$ positive samples, while higher prevalence was recognized by Amany (2000) who had $86.24 \%$ positive samples.

Among 203 bacteriological positive lung samples, 124 (60.49\%) of apparently healthy lungs were bacteriological positive which partially confined with Thabet (1994) who his incidence was (71.8\%) and disagreed with Azzam and Zaki (2006) who recorded lower prevelance $(26.66 \%)$. 
Meanwhile,79 (76.7\%) of pneumonic lungs were culturally positive for bacteria which partially agreed with Azzam and Zaki (2006) who found that $(79 \%)$ of pneumonic samples were bacteriological positive. Higher incidences were estimated by Moustafa (2004) who recorded (96\%) of pneumonic samples were bacteriological positive. Lower percentages were recorded by Fatma et al. (2001) who found (56\%) of pneumonic samples were bacteriological positive.

The isolated bacteria may be present singly or mixed with other. It was noticed from the same table that out of 203 bacterial positive lungs, $104(51.23 \%)$ samples had single infection that partially agreed with Amany (2000) who recovered single isolates from (65\%) of lung samples. On the other hand, $99(48.77 \%)$ samples yielded mixed infection who found that was nearly similar to Nagi et al. (1997) who found that $(43.85 \%)$ yielded mixed infected samples.

In the present study, the incidences of samples yielded single and mixed infection from apparently healthy lungs of camels were 74 $(59.68 \%)$ and $50(40.32 \%)$, respectively, this result disagreed with Azzam and Zaki (2006) who recorded that the incidence were (85.71\%) and (14.29\%) for single and mixed samples of apparently healthy lung of camels, respectively.

On the other hand, prevalence of pneumonic lung samples yielded single isolates was $30(37.97 \%)$ which was approximately similar to Moustafa (2004) who recorded the incidence of samples yielded single isolates from pneumonic lungs was $(41.7 \%)$. 
The incidence of samples yielded mixed isolates from pneumonic lungs was 49 (62.03\%) which confined to some extent Moustafa (2004) who found that $(58.3 \%)$ of samples yielded mixed isolates from pneumonic lungs.

These findings declared that the highest samples yielded single bacterial isolates than mixed ones were found in apparently healthy lungs, which agreed with Thabet (1994). Meanwhile, the contrast occurs as the highest samples yielded mixed isolates were more than that yielded single

The current investigations revealed that 302 bacterial isolates recovered from lungs of slaughtered camels classified as 132 (43.71\%) Gram positive and 170 (56.29\%) Gram negative isolates out of which, 174 were recovered from apparently healthy lungs that classified as 80 (45.98\%) of Gram positive and 94 (54.02\%) of Gram negative isolates. These results were partially confined with Moustafa (2004) and disagreed with Amany (2000) who isolated (78.13\%) of Gram positive and $(21.88 \%)$ of Gram negative bacteria.

However, the number of isolates were 128 from pneumonic lungs, distributed as 52 (40.63\%) of Gram positive and 76 (59.38\%) of Gram negative isolates which were nearly in accordance with Amer et al. (2002) who found that the incidence of Gram positive were $(54.7 \%)$ and (45.33\%) of Gram negative isolates respectively, and disagreed with $\boldsymbol{A l}$ Doughaym et al. (1999) who had (82.4\%) of Gram positive and (15\%) of Gram negative isolates from pneumonic lungs.

These variations in our data compared with others may be due to location, country, husbandary, feeding and immunity. 
Meanwhile, the highest number of Gram negative bacteria obtained from apparently healthy lungs was $E$. coli with an incidence of 29 (16.67\%) which partially agreed with Aly et al. (2004) who found that $E$. coli was the main Gram negative isolate from apparently healthy lungs with an incidence of (22.2\%) and disagree with Moustafa (2004) who isolated $E$. coli with a percentage of $(2.94 \%)$ from apparently healthy lungs.

Many other Gram negative isolates were recovered from apparently healthy lungs such as Citrobacter freundii with an incidence of 11 (6.32\%), Proteus penneri 9 (5.17\%), Citrobacter spp., K. oxytoca and Y. enterocolitica with an incidence of $8(4.6 \%)$ in each, Enterobacter cloacae 7 (4.62\%), Pseudomonas aeruginosa 6 (3.45\%), P. vulgaris 5 $(2.87 \%)$ and finally, K. ozaenae $3(1.72 \%)$.

Isolation of Citrobacter spp. from apparently healthy lungs of camels was previously recognized by Amany (2000). Pseudomonas aeruginosa was isolated by Ebtesam et al. (2009).

P. vulgaris from apparently healthy lungs of camels was previously recorded by Moustafa (2004) but with different incidences.

Klebsiella spp. were isolated from apparently healthy lungs of camels by Hanea and Omnia (2002) and Thabet (1994) who found Klebsiella spp. in incidence of (4.9\%).

New isolates were isolated from apparently healthy camel lungs such as P. penneri, K.oxytoca, K. ozaenae, Entrerobacter cloacae and $Y$. enterocolitica that were not previously recorded by other authors. 
These results indicated that apparently healthy lungs act as a reservoir for many species of pathogenic and potential pathogenic microorganisms that under stress factors such as changes in the hygiene, environmental and climatic conditions may play a role in the onset of pneumonia Zubair et al. 2004). This concept was supported in the present study by the fact that a number of bacteria were isolated from 124 samples which showed no pathological lesions.

On the other hand, the highest number of Gram negative isolates was E. coli with an incidence of $(15.63 \%)$ that agreed with Amer et al. (2002) who found that E. coli was the predominant isolate of Gram negative bacteria recovered from pneumonic lungs but with different percentages.

The other Gram negative bacteria incriminated in camel pneumonia were K. pneumoniae 12 (9.38\%), Ps. aeruginosa 10 (7.81\%), K. oxytoca and $Y$. enterocolitica with an incidence of $6(4.69 \%)$ in each, Citrobacter freundii 5 (3.91\%), P. penneri 4 (3.13\%), Citrobacter spp. and Enterobacter cloacae with an incidence of $3(2.34 \%)$ in each, K. ozaenae and finally $P$. multocida with an incidence of $1(0.78 \%)$ in each.

Incidence of E. coli was partially agreed with Seddek (2002) who isolated E. coli from $10.58 \%$ of pneumonic samples while disagreed with Al-Doughaym et al. (1999) who detected E. coli with an incidence of $6.2 \%$.

Klebsiella pneumoniae was observed by Nagi (2004). Similar incidence was showed by Al-Doughaym (1999) who obtaine Klebsiella pneumoniae from (10.9\%) of pneumonic samples and disagreement occurred with Amer et al. (2002) who obtained Klebsiella pneumoniae from $(3.8 \%)$ of pneumonic lungs. 
Pseudomonas aeruginosa was detected from pneumonic lungs by Al-Tarazi and El-Sheikh (2006). The incidence of Pseudomonas aeruginosa is partially agreed with Seddek (2002) who obtained Pseudomonas aeruginosa (8.82\%) from pneumonic lungs, while disagreed with Asil et al. (2004) who found Pseudomonas aeruginosa in an incidence of (1\%) of pneumonic lungs.

Klebsiella oxytoca and Klebsiella ozaenae were previously recovered by $\boldsymbol{A l - T a r a z i}$ (2001) from pneumonic lungs.

Lower percentage of Yersinia enterocolitica was recorded by Fatma et al. (2001) who isolated Yersinia enterocolitica from (1.26\%) in pneumonic lung samples whereas higher incidence (9.4\%) was recorded by Amer et al. (2002).

Citrobacter spp. were observed by Abubakr et al. (1999). The incidence was agreed with Seddek (2002) who isolated Citrobacter spp. from $(2.35 \%)$ of pneumonic samples and partially coincided with Fatma et al. (2001) who revealed it in a lower incidence of (1.26\%).

Citrobacter freundii was showed by Wernery and Kaaden (2002). The incidence was partially agreed with Fatma et al. (2001) who found Citrobacter freundii in an incidence of $2.53 \%$ from pneumonic lungs of camels.

Proteus spp. were previously observed from pneumonic lungs by Kane et al. (2005).

Proteus vulgaris was recognized by Mahmoud et al. (1988) while Proteus penneri was previously obtained by Fatma et al. (2001) with lower percentage (1.26\%). The incidence of Proteus vulgaris is partially 
agreed with Fatma et al. (2001) who isolated it with an incidence of $(1.26 \%)$ while higher percentage $(9.46 \%)$ was isolated by Zaitoun (1986).

Pasteurella spp. were isolated by many searchers from pneumonic lungs such as Asil et al. (2004) and Nagi (2004). Also, Pasteurella multocida was recognized by Al-Ani (1990) whilst Mannheimia haemolytica was detected by Al-Tarazi and El-Sheikh (2006).

In the present work, Mannheimia haemolytica was recovered with a percentage of $1.56 \%$ which partially agreed with Fatma et al. (2001) who isolated it in incidence of $(1.17 \%)$ from pneumonic lung samples.

Meanwhile, Pasteurella multocida was isolated with a percentage of $0.78 \%$ which is lower than that recorded by Seddek (2002) and Susan et al. (2000) who isolated (14.2\%) from pneumonic lungs. The low percentage of isolated Pasteurella spp. was supported by Magda (1998) who stated that camels are less susceptible to Pasteurella infection than other animals.

Enterobacter spp. were revealed by Asil et al. (2004) from pneumonic lungs with various prevalences.

It was clear from Table (5) that 74 samples yielded single bacteria 1 isolates from apparently healthy lungs of slaughtered camels that were classified into two categories, Gram positive and Gram negative bacterial isolates.

On the other hand, the highest incidence of Gram negative single bacterial isolates was E. coli $21(28.38 \%)$ followed by Citrobacter freundii 7 (9.46\%), Citrobacter spp. 5 (6.76\%), Pseudomonas aeruginosa $4(5.41 \%)$, Klebsiella oxytoca $3(4.05 \%)$, Yersinia enterocolitica 2 (2.7\%) and Klebsiella ozaenae 1 (1.35\%). 
On the other hand, the most prevalent single isolate of Gram negative bacteria from pneumonic lungs of camels was E. coli in 7 samples with an incidence of $(23.33 \%)$ then Klebsiella pneumoniae 6 (20\%), Pseudomonas aeruginosa 5 (16.67\%), Mannheimia. haemolytica $2(6.67 \%)$ and Pasteurella multocida 1 (3.33\%).

These findings were partially agreed with Azzam and Zaki (2006) who isolated E. coli, Pasteurella haemolytica and Pasteurella multocida with incidence of $26 \%, 10 \%$ and $5 \%$, respectively.

Lower incidences of Pseudomonas aeruginosa and Klebsiella pneumoniae were showed by Moustafa (2004), Azzam and Zaki (2006) and Amany (2000) who noticed Pseudomonas aeruginosa and Klebsiella pneumoniae as single isolates in pneumonic samples with percentages of $3.85 \%$ and $1.92 \%$, respectively.

Higher incidences of Pasteurella multocida obtained by Amany (2000), Selim (2003) and Moustafa (2004) who isolated Pasteurella multocida from $(8.3 \%)$ of pneumonic samples.

However, Table (5) noticed that out of 104 samples revealed single isolates of bacteria, 74 samples from apparently healthy lungs with an incidence of $(71.15 \%)$ and 30 samples from pneumonic lungs with an incidence of $(28.85 \%)$ yielded single isolates. The higher number of samples yielded single isolates was recovered from apparently healthy lungs. The recovered organisms were classified into two categories, Gram positive and Gram negative bacterial isolates. The most common Gram negative single isolates were $E$. coli in 28 lung samples with an incidence of 26.92\% followed by Pseudomonas aeruginosa 9 (8.65\%), Citrobacter freundii 7 (6.73\%), Klebsiella pneumoniae 6 (5.77\%), Citrobacter spp. 5 
(4.81\%), Klebsiella oxytoca 3 (2.89\%), Mannheimia haemolytica and Yersinia enterocolitica with an incidence of $2(1.92 \%)$ in each and finally Klebsiella ozaenae and Pasteurella multocida with an incidence of $(0.96 \%)$ in each.

It was declared from Table (6) that bacteria isolated from apparently healthy lungs may occur in a mixed form mainly as a combination between Proteus penneri and Micrococcus spp. (18\%), Staph. aureus with each of Enterobacter cloacae (14\%), non haemolytic streptococci (14\%), E. coli (12\%) and Klebsiella oxytoca (10\%) or another combination between Micrococcus spp. with each of Citrobacter spp. (6\%) and E. coli (4\%). Also, there was a combination between Proteus vulgaris with each of non haemolytic streptococci (6\%) and Pseudomonas aeruginosa (4\%) as well as Yersinia enterocolitica with each of Citrobacter freundii (8\%) and Klebsiella ozaenae (4\%).

The current investigation from Table (6) showed that the bacteria causing pneumonia in camel may occur in a mixed form consisted mainly of Citrobacter freundii with Yersinia enterocolitica or Staphylococcus aureus with Klebsiella pneumoniae with an incidence of $(10.2 \%)$ in each.

Also, there were combinations between Staph. aureus with each of E. coli (8.16\%), Enterobacter cloacae (6.12\%), Klebsiella oxytoca (6.12\%), non haemolytic streptococci (6.12\%) and Diplococcus pneumoniae (4.09\%). There was sharing between Micrococcus spp. and each of Proteus penneri (8.16\%), E. coli (4.09\%) and Klebsiella pneumoniae (2.04\%) as well as Diplococcus pneumoniae with each of Pseudomonas aeruginosa (8.16\%) and E. coli (4.09\%). 
The incidences of Diplococcus pneumoniae with Pseudomonas aeruginosa and Staphylococcus aureus with each of E. coli and Enterobacter cloacae were higher than those isolated by Fatma et al. (2001) and Seddek (2002) who recognized lower percentage of (1.44\%), $(2.89 \%)$ and $(1.44 \%)$, respectively.

Combination between Diplococcus pneumoniae with E. coli was agreed with that recorded by Azzam and Zaki (2006) who had a percentage of $(4 \%)$ from pneumonic samples.

Combination between Staph. aureus with non haemolytic Streptococci was previously recognized by Fatma et al. (2001) but with lower percentage $(1.67 \%)$.

In the present study, it was noticed that Staphylococcus aureus was the highest mixed isolate isolated from pneumonic lungs of camels which is supported by El-Haenaeey et al. (1994).

Amany (2000), Fatma et al. (2001), Seddek (2002), Selim (2003), Moustafa (2004) and Azzam and Zaki (2006) isolated different mixed bacterial isolates from pneumonic lungs including Staph. aureus with Pasteurella multocida, E. coli with Klebsiella pneumoniae, Strept. pneumoniae with Coryn. pyogenes, Micrococcus spp. with Citrobacter freundii and Staphylococcus aureus with Yersinia enterocolitica. This may be attributed to changes in environment, hygienic conditions, nutritional factors and immune status of the animal (Fatma et al. 2001).

It was clear from Table (6) that mixed isolates recovered from both apparently healthy and pneumonic lungs were mainly composed of Proteus penneri and Micrococcus spp. with an incidence of 13 (13.13\%) followed by Staphylococcus aureus with each of E. coli, Enterobacter 
cloacae and non haemolytic Streptococci with an incidence of 10 (10.10\%) for each, Citrobacter freundii with Yersinia enterocolitica 9 (9.1\%), Staph. aureus with Klebsiella oxytoca 8 (8.08\%), non haemolytic streptococci with Proteus vulgaris 5 (5.05\%), Staph. aureus with Klebsiella pneumoniae 5 (5.05), Diplococcus pneumoniae with Pseudomonas aeruginosa 4 (4.04\%) and Micrococcus spp with E. coli 4 (4.04\%) while, Arcanobacterium pyogenes with Citrobacter spp., Klebsiella oxytoca with E. coli, Klebsiella ozaenae with Yersinia enterocolitica and Micrococcus spp. with Citrobacter spp. were equal in an incidence of $3(3.03 \%)$ in each. Also, the prevalence of Diplococcus pneumoniae with E. coli was equal to that of Pseudomonas aeruginosa with Proteus vulgaris and that of Staph. aureus with Diplococcus pneumoniae in two samples with an incidence of 2 (2.02\%) in each.

The least mixed isolates were Klebsiella ozaenae with E. coli, Micrococcus spp. with Klebsiella pneumoniae and Pseudomonas aeruginosa with E. coli in one sample with an incidence of 1(1.01\%) in each.

It was clear from Table (7) that serological identification of all the strains of E. coli isolated from apparently healthy and pneumonic lungs of slaughtered camels revealed 29 isolates from apparently healthy and 20 from pneumonic lungs.

There variations in incidence of serogroups isolated from apparently healthy lungs as $E$. coli $O_{111}$ was the most predominant serogroup with an incidence of $6(20.68 \%)$ followed by E. coli $O_{125}$ and E. coli $O_{166}$ with an incidence of $5(17.24 \%)$ for each, E. coli $O_{146}$ with an incidence of $4(13.79 \%)$ then E. coli $O_{55}$, E. coli $O_{115}$ and E. coli $O_{119}$ with an incidence of $3(10.35 \%)$ in each. 
Meanwhile, in pneumonic lungs, the most predominant serogroup was $E$. coli $O_{55}$ with an incidence of $5(25 \%)$ followed by E. coli $O_{166}$ with an incidence of $4(20 \%)$, E. coli $O_{119}$ and E. coli $O_{125}$ with an incidence of $3(15 \%)$ in each, E. coli $O_{111}$ and $E$. coli $O_{146}$ with an incidence of $2(10 \%)$ in each and finally, E. coli $O_{115}$ with an incidence of $(5 \%)$.

This assumption was supported by El-Battrawy et al. (1992) who isolated E. coli $\mathrm{O}_{111}$ and $E$. coli $\mathrm{O}_{125}$ from healthy and diseased animals and partially agreed with Fatma et al. (2001) in isolation of E. coli $O_{125}$ and $E$. coli $O_{166}$ and disaggreed with Thabet (1994), Amany (2000) and Azzam and Zaki (2006) who isolated E. coli $O_{86}$ and E. coli $O_{126}$ from pneumonic lungs of camels.

Regarding to the pathogenicity of the bacterial isolates, it was clear from Table (8 and 9) that the highest pathogenic bacteria of Gram positive bacterial isolates were Arcanobacterium pyogenes and Diplococcus pneumoniae with an incidence of $(100 \%)$ in each, followed by Micrococcus spp. (60\%), non haemolytic streptococci and Staphylococcus aureus with an incidence of (40\%) in each.

Meanwhile, the highest pathogenic bacteria of Gram negative bacterial isolates were $E$. coli $O_{55}$, E coli $O_{115}$, Klebsiella pneumoniae, Mannheimia haemolytica, Pasteurella multocida and Pseudomonas aeruginosa with an incidence of $(100 \%)$ for each followed by E. coli $O_{125}$, E. coli $O_{146}$ and $E$. coli $O_{166}$ with an incidence of $(60 \%)$ in each, Citrobacter freundii, E.coli $O_{111}$, Enterobacter cloacae, Klebsiella oxytoca, Klebsiella ozaenae and Yersinia enterocolitica with an incidence of (40\%) in each as well as E. coli $O_{119}$ and Proteus vulgaris with an incidence of $20 \%$ in each. 
On the other hand, Citrobacter spp. and Proteus penneri were not being found to cause deaths among mice.

These findings agreed with Buchnev et al. (1987), Refai (1990), Amany (2000), Omnia and Amer (2003) and Moustafa (2004) who revealed death of $(100 \%)$ of injected mice by Pasteurella multocida and partially agreed with Susan et al. (2000) who found that $81 \%$ of Pasteurella multocida and $33 \%$ of Pasteurella haemolytica had killed (100\%) of mice within 24 hours post injection apparently healthy and diseased camels.

Concerning in-vitro antibacterial sensitivity, it was clear from Table (10 and 11), that there is a marked difference between the sensitivity to antibiotics between different bacterial isolated from apparently healthy and pneumonic lungs of slaughtered camels.

These findings were concided with Amany (2000), Al-Tarazi and El-Sheikh (2006) who found that most of isolates from pneumonic lungs of camels were sensitive to Ciprofloxacin, Enrofoxacin and Gentamicin and partially agreed with Hanea and Omnia (2002).

It was noticed from Table (13) that the most effective antibiotics for Gram negative isolates from apparently healthy and pneumonic lungs of slaughtered camels were Enrofloxacin, Norfloxacin then Gentamicin, Ciprofloxacin and Flumequine then Doxycycline and Chloamphenicol but most of bacterial isolates were resistant to Cloxacillin, Penicillin, Streptomycin and Trimethoprim.

These findings were coincided with Amer et al. (2002) and Hawari (2008). 
E. coli serogroups were highly sensitive to Enrofloxacin, Norfloxacin also; Gentamicin except $E$. coli $O_{125}$, while $E$. coli $O_{119}, E$. coli $O_{146}$ and $E$. coli $O_{166}$ were sensitive to Ciprofloxacin and E. coli $\mathrm{O}_{125}$ was sensitive to Flumequine.

Similar observations were noticed with Moustafa (2004) who found that $E$. coli was sensitive to Enrofloxacin and Gentamicin.

Enterobacter cloacae isolates were sensitive to Ciprofloxacin, Enrofloxacin and Norfloxacin followed by Flumequine while were resistant to Chloramphenicol, Cloxacillin, Doxycycline, Gentamicin, Penicillin, Streptomycin and Trimethoprim.

As shown from this table that the most effective antimicrobial agents against Klebsiella oxytoca, Klebsiella ozaenae and Klebsiella .pneumoniae were Enrofloxacin, Flumequine and Norfloxacin. K.oxytoca and K.ozaenae were sensitive to Gentamicin while K. pneumoniae was resistant. They were resistant to the other antimicrobial agents.

Hanea and Omnia (2002) who found that Klebsiella spp. were sensitive to Enrofloxacin, Gentamicin and Penicillin.

Klebsiella pneumoniae was sensitive to Enrofloxacin, Flumequine and Norfloxacin and resistant to Gentamicin which agreed with $\boldsymbol{A b \boldsymbol { B }} \boldsymbol{E} \boldsymbol{l}$ Motelib and El-Zanaty (1993).

Mannheimia haemolytica was sensitive to Doxycycline and Enrofloxacin and Norfloxacin and resistant to the other antimicrobial agents.

Pasteurella multocida was sensitive to Doxycycline and Enrofloxacin and resistant to other antimicrobial agents. This agreed with Ahmed et al. (1986) who found that it was resistant to Penicillin and 
partially agreed with Moustafa (2004) who found that Pasteurella multocida was sensitive to Chloramphenicol and Gentamicin and resistant to Streptomycin while disagreed with Selim et al. (2003) and Azzam and Zaki (2006) who revealed that Pasteurella multocida was sensitive to Norfloxacin.

Proteus penneri and Proteus vulgaris were sensitive to Ciprofloxacin, Enrofloxacin and Norfloxacin and resistant to the other types of antimicrobial agents.

Pseudomonas aeruginosa isolates were sensitive only to Enrofloxacin and resistant to the other types of antimicrobial agents which supported by Thabet (1994) and Amer et al. (2002) who found that Pseudomonas aeruginosa was sensitive to Enrofloxacin.

Yersinia enterocolitica was highly sensitive to Doxycyline and Enrofloxacin, Meanwhile, It was resistant to the other types of antimicrobial agents which partially agreed with Amer et al. (2002).

It was clear that most of bacterial isolates were resistant to most antibiotics and this may be attributed to wrong dosage, duration of treatment and route of administration (Amstutz et al., 1982).

These variations in sensitivity may be due to bacterial nature, distribution of bacteria or regional difference and plasmid helping in the formation of resistant strains. In consideration of the most effective in vitro antibacterial agents against all tested isolates, Enrofloxacin should be the drug of choice in controlling pneumonia in camel.

In this work, the whole cell protein of ten strains including 3 Klebsiellae; Klebsiellae pneumonia, Klebsiellae oxytoca and Klebsiellae ozaenae as well as 7 srains of E. coli including E. coli $\mathrm{O}_{55}$, E. coli $\mathrm{O}_{111}$, 
E. coli $\mathrm{O}_{115}$, E. coli $\mathrm{O}_{119}$, E. coli $\mathrm{O}_{125}$, E. coli $\mathrm{O}_{146}$ and E. coli $\mathrm{O}_{166}$ had been analyzed and Sodium Deodecyl Sulphate Polyacrylamide Gel Electrophoresis (SDS-PAGE) profiles of these strains were determined. This powerful technique allows very high resolution of protein and has permitted the identification of multiple major proteins components of different molecular weights.

SDS-PAGE analysis of Klebsiellae and E. coli showed that they contained from 5 to 12 bands after staining with Commiassie brilliant blue method which molecular weight ranged from 7.218 to $170.97 \mathrm{KDa}$.

It was obvious that the molecular weight of E. coli $\mathrm{O}_{55}$ ranged from 134.55 to $7.2118 \mathrm{KDa}$. The molecular weight of $E$. coli ${ }_{111}$ ranged from 134.55 to $32.208 \mathrm{KDa}$. The molecular weight of $E$. coli $\mathrm{O}_{115}$ ranged from 134.55 to $33.311 \mathrm{KDa}$. The molecular weight of E. coli $\mathrm{O}_{119}$ ranged from 131.24 to $8.4471 \mathrm{KDa}$. The molecular weight of $E$. coli $\mathrm{O}_{125}$ ranged from 118 to $28.562 \mathrm{KDa}$. The molecular weight of E. coli $\mathrm{O}_{146}$ ranged from 151.11 to $11.741 \mathrm{KDa}$. The molecular weight of E. coli $\mathrm{O}_{166}$ ranged from 154.41 to 21.137.

On the same hand the molecular weight of Klebsiella oxytoca ranged from 157.72 to $15.859 \mathrm{KDa}$. The molecular weight of Klebsiella pneumoniae ranged from 167.66 to $22.15 \mathrm{KDa}$. The molecular weight of Klebsiella ozaenae ranged from 170.97 to $38.016 \mathrm{KDa}$. It was noticed that there was a shared band in molecular weight of (E. coli $\mathrm{O}_{111}$, lane 2), ( E. coli $\mathrm{O}_{115}$,lane 3), (E. coli $\mathrm{O}_{146}$, lane 6),(E. coli $\mathrm{O}_{166}$, lane 7) and (Klebsiella ozaenae, lane 10) in $102.56 \mathrm{KDa}$, (E. coli $O_{125}$, lane 5) and(Klebsiella oxytaca, lane 8) in 103.56KDa and (E. coli $\mathrm{O}_{55}$, lane 1), (E. coli $\mathrm{O}_{111}$, lane 2) and (E. coli $\mathrm{O}_{115}$, lane 3) in 74.588. On the other 
hand, there was sharing to large extant in molecular weight of band between (E. coli $\mathrm{O}_{111}$, lane 2) 42.647KDa, (E. coli $\mathrm{O}_{119}$, lane 4) 42.937 $\mathrm{KDa}$ and (E. coli $\mathrm{O}_{125}$, lane 5) $42.647 \mathrm{KDa}$ and between (E. coli $\mathrm{O}_{146}$, lane 6) $40.911 \mathrm{KDa}$ and (E. coli $\mathrm{O}_{166}$, lane 7) $40.621 \mathrm{KDa}$ and finally between (Klebsiella oxytoca, lane 8) $41.489 \mathrm{KDa}$ and (Klebsiella ozaenae, lane 10) $41.489 \mathrm{KDa}$. Also there was sharing to large extant in molecular weight of other band which was observed in (E. coli $\mathrm{O}_{55}$, lane 1) $32.576 \mathrm{KDa}$ and (E. coli $\mathrm{O}_{111}$, lane 2) $32.208 \mathrm{KDa}$. and between ( $E$. coli $\mathrm{O}_{115}$, lane 3) $33.311 \mathrm{KDa}$. and (E. coli $\mathrm{O}_{119}$, lane 4 ) $33.678 \mathrm{KDa}$. and between (E. coli $\mathrm{O}_{146}$, lane 6 ) $34.956 \mathrm{KDa}$. and (E. coli $\mathrm{O}_{166}$, lane 7 ) $34.414 \mathrm{KDa}$. and finally between (E. coli $\mathrm{O}_{125}$, lane 5 ) $36.568 \mathrm{KDa}$. and (Klebsiella ozaenae, lane 10 ) 36.016. It was noticed that (E. coli $\mathrm{O}_{55}$, lane 1), (E. coli $\mathrm{O}_{111}$, lane 2), (E. coli $\mathrm{O}_{115}$, lane 3) and (E. coli $\mathrm{O}_{119}$, lane 4) shared in major crude protein 134.55, 134.55and 134.55 KDa. This greed to some extent with Durrani et al. (2008) who recorded that the major molecular weights of E. coli strains were ( 97.4 and $133 \mathrm{KDa}$ ). and minor molecular weight $(18,25$ and $48 \mathrm{KDa})$. It could be primarly differentiate between examined E. coli and Klebsiellae with SDS. No clear pattern could be established between specific serotypes of E. coli in relation to SDS bands.

\section{REFERENCES}

- Abd El-Motelib,T. Y. and El-Zanaty, K. (1993): Staphylococcus and Klebsiella infection in broiler chickens. Assiut. Vet. J., 50: 270-278.

- Abubakr, M. I.; Nayel M. N. and Fadlallah, M. E. (1999): "Corynebacterium abscess in camels Bahrain". J. Camel Practice and Research, 6 (1):107- 109. 
- Al-Ani, F. K. (1990): Common respiratory diseases of Iraqi camels. In: Proc. Symposium on camel breeding, diseases and their control. Arab Organization for Agricultural Development (AOAD), Alger, 2426 March 1990, p. 283-287.

- Alhendi, A. A. B. (2000): Common diseases of camels (Camelus dromedaries) in Eastern province of Saudi Arabia. Pakistan. Vet. J., 20 (2): 97-99.

- Ahmed, R.; Amin, M. and Karzmi, S. E. (1986): Studies on bacterial cause of calf mortality. Pak. Vet. J., 6(3):116-118.

- Amany, N. D. A. (2000): A contribution towards the bacteria harboring and affecting the respiratory tract of camel. M.V.Sc. Thesis. Fac. Vet. Med. Cairo Univ.

- Amer, H. A.; Omnia, F. H. B. and Salem, S. A. H. (2002): "Diagnosis of some respiratory diseases in camel calves". Minufyia Vet. J., 2(1): 113-135.

- Amstutz, H.; Morte, R. and Armostrong, C. (1982): Antimicrobial resistance of strains of Pasteurella spp. isolated from feedlot cattle. Bovine Practice, 16: 52-55.

- Al-Doughaym, A. M.; Mustafa K. M. and Mohamed, G. E. (1999): Aetiological study on pneumonia in camel (Camelus Dromedarius) and in vitro antibacterial sensitivity pattern of the isolates. Pakistan J. Biol. Sci, 2(4): 1102-1105.

- Al-Tarazi, Y. H. and El-Sheikh, H. (2006): In vitro sensitivity against bacterial pathogens isolated from pneumonic lungs of camels in Jordan. J. of Camel Practice and Research, 13 (2): 157-163. 
- Al-Tarazi, Y. H. (2001): Bacteriological and pathological study on pneumonia in the one-humped camel (camelus dromedarius) in Jordan. Revue d' Elevage et de medicine veterinaire des pays Tropicaux, 54 (2): 93 - 97.

- Aly, A. A.; Soliman, A. S. and Gobran, R. A. (2004): Bacteriological and pathological studies on some lung affections of camels at Kalubia governate. Mansoura Vet. Med. J. Vol., VI (1): 75-86

- Asil E.; Abdul Khalig, B. and Adam, A. (2004): Studies on pathological changes of condemned lungs of one humped camels (camelus dromedarius). Deutscher Tropentag octobar 5-7 Brelin Rural poverty Reduction through research for development.

- Azzam, I. M. and Zaki, H. M. (2006): Laboratory investigation on bacterial pneumonia in camels. Egypt. J. Comp. Path. and Clinic Path. 19(1): 319-344.

- Baba, S. S.; Amball, A. G.; Zaria, L. T. and Kalra, S. (1994): Abattoir records of slaughtered camels. Bull. Anim. Hlth. Prod. Afr., 42(3):253-257.

- Barrow, G. L. and Feltham, R. K. (1993): Cowan and steel's. Manual for identification of medical bacteria, $3^{\text {rd }}$ Ed., University Press, Cambridge.

- Buchnev, K. N.; Tulepaev S. Z., and Sansyzbaev, A. R. (1987): "Infections disease of camels in the USSR". Rev. Sci. Tech. Off. Int. Epizoot, 6(2):487-495.

- Chowdhary B. (1986): Some important biological and production characters of the Bikaner camels. Ind. J. Anim. Prod. Manag., 2(3): 145-151. 
- Cowan, S. T. (1979): Manual for the identification of medical bacteria. Cambridge University Press.

- Cruickshank, R.; Dugid, J. P.; Marmion, B. P. and Swain, R. H. (1975): The Practice Medical Microbiology, 12th Ed. Vol. II Churchill Living Stone, Edinburgh, London and New York.

- Durrani, R. ; Abubakar, M.; Arshed ,M. J.; Saleha ,S. ;Ulah ,I. and Ali, Q. (2008): Biological characterization and protein profile of two model bacteria by SDS-PAGE and FT-IR. APRN J. of Agricultural and Biological Science, Vol. 3 No (5\&6): 6-16.

- Ebtesam, M. M.; Ibrahim, H. M. and Sharaf, E. M. (2009): Some studies on bacteria isolated from respiratory system of apparently healthy camels in Qulybia governorate. Zag., Vet. J.,Vol.37(1): 62-66.

- Edwards, P. R. and Ewing, W. H. (1972): Identificaion of Enterobacteriaceae. Minneapolis, Burgess Publishing Co.,:709.

- El-Battrawy, N. E.; El-Garhy, M. M.; El-Rashidy, A. A.; Girgis, S. M. and Tawfik, M. S. (1992): Incidence of microorganisms isolated from respiratory tract of apparently healthy and diseased buffalocalves. Beni Suef Vet. Med. Res.,2 (1): 366-375.

- El-Haenaeey, A.; Mahmoud, O. M. and Haroun, E. M. (1994): Bacterial isolates from respiratory tract of cattle and their zoonotic importance in Al-Quassem, Saudi Arabia. Vet. Med. J. Giza, 42(1): 189-196.

- Emery, D. A; Nagarja, K. V; Shaw, D. P; Newman, J. A. and White, D. G. (1992): Virulence factors of E. coli associated with colisepticeamia in chiken and turkey. Avian Dis., 36: 504- 511. 
- Fatma, M. Darwish; Hammad, A. M. and Hala, S. Ibrahim (2001): Pathological studies on pneumonia in camels with special reference to mycotic and bacterial infection. J. Egypt. Vet. Med. Ass., 61 (2): 143-172.

- Finegold, S. M. and Martin, W. T. (1982): Diagnostic Microbiology. $6^{\text {th }}$ Ed.,The C.V. Mosby Company U.S.A.

- Hanea, A. A.A. and Omnia, F. H. B. (2002): Diagnosis of some respiratory diseases in camel calves. Minufyia.Vet. Med. J., 2 (1).

- Hawari, A. D. (2008): Corynebacterium pseudotuberculosis infection (caseous lymphadenitis) in camels (Camelus dromedarius) in Jordan. American J. of anim. And Vet. Sci. 3 (2): 68 - 72.

- Kane, Y.; Kadja, M. C.; Bada-Alambedji ,R.; Bezeid ,O. E.; Akakapo, J. A. and Kaboret, Y. (2005): Lung lesions and bacteria of the one-humped camel (Camelus dromedaries) at Nouakchott slaughterhouse in Mauritania. Revue Élev. Méd. Vét. Pays Trop., 58(3): 145-150.

- Khanna, N. D.; Tandon, S. N.; Sahani ,M. S.; Allen,W. R.; Higgins, A. J.; Mayhew, I. G.; Snow ,D. H. and Wade, J. F. (1992): Calf mortality in Indian camels. Proceedings of the first international camel conference, Dubai, $2^{\text {nd }}-6^{\text {th }}$ February 1992: 89-92.

- Koneman, E. W.; Allen, S. D.; Dowel, V. R. and Sommers, H. M. (1983): Colour Atlas and Text Book of Diagnostic Microbiology. $2^{\text {nd }}$ Ed. J.B. Lippincott Co., New York, London.

- Koneman, E. W.; Allen, S. D.; Dowel, V. R.; Sommers ,H. M.; Janda, W. M. and Winn, W. C. (1988): Colour Atlas and Text Book of Diagnostic Microbiology. $3^{\text {rd }}$ Ed. J. B. Lippincott, Co, Philadelphia, U.S.A. 
- Kreig, N. R. and Holt, J. G. (1984): Bergey's Manual of Systemic Bacteriology. $8^{\text {th }}$ Ed.Williams and Wilkins,Baltimore,London:11-117.

- Laemmli, U. K. (1970): Cleavage of structural proteins during the assembly of the head of bacteriophage T4.Nat.(London) 227:680-685.

- MacFaddin, J. E. (1976): Biochemical tests for identification of medical bacteria. $1^{\text {st } E d . ~}$

- Mackie, T. J. and MacCarteny, J. E. (1989): Practical Medical Microbiology. $13^{\text {th }}$ Ed. Churchill Livingstone, London.

- Magda, M. M. O. (1998): Serological studies on some Pasteurella strains in camel. PH. D. Thesis. Fac. Vet. Med. Zagazig Univ.

- Mahmoud, A. Z.; Sabah, I. M. and El-yas, A. H. (1988): "A study on lung affections of camels (camelus dromedarius) in Assuit governorate". Assuit Vet. Med. J., 20: 93-99.

- Moustafa, A. H. (2004): "A study on some aerobic bacterial causes of respiratory affection in slaughtered camels in Dakahlia governate". Assiut Vet. Med. J., Vol 5o (102): 95-105.

- Nagi, A. E. S. (2004): Bacterological and histopathological studies on some lung affection of camel at kaloubia governorate. Mansoura. Vet. Med. J.

- Nagi, A.; Gaballh, M. S.; El-Mashad, A. L. and Abd El-Aziz, A. M. (1997): Pathological studies on some lung affections in camel (Camelus Dromedarius), at Kalubia province. Benha Vet. Med. J., 8 (2): 209-223. 
- Ning, J.; Nuaitae, C. and Xuanren, Z. (1998): Study on pneumoconiosis in Bactrian camels. Chin. J. Vet. Sci., 18(2):186-190.

- Omnia, F. H. Badawy and Amer, H. A. (2003): Comparative studies between Mannheimia (Pasteurella) haemolytica isolated from pneumonic lungs of camel calves and lambs through histopathological examination and cytotoxic effect. J. Egypt. Vet. Med. assoc. 63 No. 1:21-33.

- Oxoid Manual (1982): The Oxoid culture media, ingradient and other laboratory service. $5^{\text {th }}$ Ed., Oxoid Limited, Hampshire, R.G.240 PW, England.

- Quinn, P. J.; Carter, M. E.; Markey, B. K. and Carter, G. R. (1994): Clinical Veterinary Microbiology. Wolfe Publishing Livestock, London.

- Quinn, P. J.; Markey, B. K.; Carter, M. E.; Donnelly, W. J. C. and Leonard, F. C. (2002): In: Veterinary Microbiology and Microbial Disease. Blackwell Science Ltd.

- Rana, M. Z.; Ahmed, A.; Sindhu, S. T. and Mohammad, G. (1993): "Bacteriology of camel lungs". Camel Newsletter, (10): 30-32.

- Refai, M. K. (1990): Bacterial and mycotic diseases of camel in Egypt. J. Vet. Med. Ass., 50(3):295-313.

- Seddek, S. R. (2002): 'Bacterial causes of lung affections in slaughtered camels in Assiut governate". Assiut Vet. Med. J., 46 (92): 169-177. 
- Selim, M. A. (2003): Bacterial isolates from pneumonic lungs of dromedary camels slaughtered at Sharkia governate. Zag.Vet. J., 31(1): 63-69.

- Stamp,J.,Watt,J.and Thomliuson,J.(1959): Pasteurella haemolytica of calves. J. Comp. Path., 65: 183-186.

- Susan, F. G.; El-Rawy, E. M.; Gergis, S. M. and Hussein A. Z. (2000): Isolation, identification of Pasteurella spp. from camels and trials for vaccine production. SCVMJ, III (1): 299 - 309.

- Thabet, A. El. R. (1994): Some microbial studies of lung of clinically healthy and respiratory infected camels. Assiut Vet. Med. J., 30 (59): 188-195.

- Wernery, M. and Kaaden, O. R. (2002): In: "Infections diseases in camelids". Backwell Wissenschoft kurfurs tendamm, Pp.133.

- Wessman, G. E. (1964): Inter-relation of smooth and non smooth variant in dissociation of Pasteurella haemolytica. J. Bact., 88: 325360.

- Zaitoun, A. M. (1986): Studies on pathogenic bacteria and fungi in lung of camels infested with Echinococcosis in Upper Egypt. M. V. Sc. Thesis (Medicine), Fac. Vet. Med., Assuit Univ.

- Zubair, R.; Khan, A. M. Z. and Sabri, A. M. (2004): Pathology in camel's lungs. J. Camel Science. (1): 103-106. 


\section{الملخص العريي}

ان الجمـال تستخدم فـى انتـاج اللحوم والألبـان والنقل الـى منـاطق صـعب الوصـول اليهـا والالتهاب الرئوى فى الجمال مشكلة نؤثر على انتاج الحيوان وتسبب خسائر خطيرة على اقتصساد

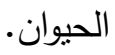

اجريت هذه الدراسة على 308 عينة من رئات الجمال المذبوحة منهم 205 عينة رئات سليمة ظاهريا و 103 عينة مصابة وقد وجد ان203 عينة بنسبة 65.91\% ايجابية للغزل البكتيرى منهم 124 عينـة بنسـبة 60.49\% ايجابيـة للعزل البكتيـرى مـن رئـات سـليمة ظاهريـا وكانـت 79 عينـة بنسبة 60.76 من رئات مصابة وقد وجد ان العترات البكتيرية فردية العزل 104 بنسبة 51.23\% بينما ثنائية العزل كانت 99 بنسبة 48.74\% منهم 74 بنسبة 68.59\% ايجابيـة للعزل الفردى من رئدات سليمة ظاهريا النى كانت اعلى من ثنائية العزل عن الرئات السليمة التى كانت 50 بنسبة 40.32\% بينما العكس فى هذه العينات كانت ثنائية العزل وهى 49 بنسبة 30.62\% اعلى فى المصـابة عن فردية العزل فى الرئات المصابة وهى 37.97\%.

وقد وجد ان العدد الكلى للمعزولات البكتيرية 302 منهم 174 من رئات سليمة ظاهريا و 128 من المعزولات من رئات مصابة وأن العدد الكلى للبكتيريا السالبة لصبغة الجرام 170 بنسبة 56.29\% منهم 94 بنسبة 54.02\% و76 بنسبة 59.38\% من رئات سليمة ظاهريا ومصابة على التوالى كما يتضح فى جدول (3).

تبين بوضوح ان اكثر المعزولات الفردية العزل وسالبة لصبغة الجرام هى معزولات الميكروب العصسوى القولـونى من 28 عينـة بنسبة 26.92\% والسودمونس ايروجـونزا 9 عينـات بنسبة 8.65\% والسـتروباكتر فيرونـــى 7 عينـات بنسـبة 6.73\% والكلبسـيلا نيمـونى 6 عينـات بنسـبة 5.77\% والستروباكتر 5 عينات (4.81\%) والكلبسيلا اوكستوكا 3عينات بنسبة 2.89\% ومانهيمانيا هيمولتيكا ويرسينيا اتيروكولنتكا 2 عينة (1.92\%) والكلبسيلا اوزونى والباستريلا ملتوسيدا عينة واحدة (0.96\%). 
امـا بالنسبة للميكروبات ثنائية العزل من رئات الجمال المذبوحة كانت اكثرهـا حدوثا بروتيس بنييري مع الميكروكوكس بنسبة 13.13\% يليه الميكروب العنقودى الذهبى مع القولونى الذى تساوى فى نسبتة هـع الميكروب العنقودى الذهبى مـع الانتروبـاكتر والعنقودى الذهبى مـع الميكروب السبحى .$\% 10.10$

وقد تم التصنيف السيرولوجى من رئات السليمة ظاهريا والمصابة من الجمال المذبوحة وذلك لككروب القولـونى يشـمل على 29 مـن العـلات البكتيريـة مـن رئـات سـليمة ظاهريـا وهـى كالتـالى 20 بينما كانت (E. coli $\mathrm{O}_{166}$, E. coli $\mathrm{O}_{146}$, E. coli $\mathrm{O}_{119}$, E. coli $\mathrm{O}_{115}$,E. coli $\mathrm{O}_{111}$ ) من العزلات البكتبرية من رئات مصابة وكانت كالتالى :

(E. coli $\mathrm{O}_{55}$, E. coli $\mathrm{O}_{111}$, E. coli $\mathrm{O}_{115}$, E.coli $\mathrm{O}_{119}$, E. coli $\mathrm{O}_{125}$, E. coli $\mathrm{O}_{146}$, E. coli $\mathrm{O}_{166)}$ ولقد وجد من اختبار الضراوة لبعض العزلات البكتيرية التى تم حقنها فى الفئران موت الفئران

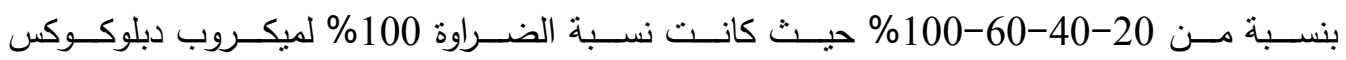
نيمونواركانوبكتبريم بيوجنس والكلبسيلا نيمونى والميكروب المتكور السبحى والسودمونس ايروجونزوا والباستريلا ملتوسيدا ومانهيمانيا هيمولتيكا بينما كانت اقلهم ضـراوة هـا الميكروب المتكور السبحي والبروتيس فالجاريس وكانت نسبتهم 20\% بينما ميكروب الستروباكتر والبروتيس بنيرى لم تنبب اى وفاة فى الفئران.

ولقد تم عمل اختبار الحساسية للمضـادات الحيويـة بالنسبة للميكروبـات المعزولـة وتبين ان كلوكسيبسلين ودوكسيسيكلين والانروفلوكساسين والجنتاميسين والنوروفلوكساسين هى الاكثر تاثيرا على ميكروب اركانوبكتيريم بيوجينس بينما السيبروفلوكساسين وكلوكساسيلين والانروفلوكساسين والجنتاميسين والنوروفلوكساسـين كانـت اكثتر المضـادات الحيويـة تـاثيرا على دبلوكـوكس نيمـونى والميكروكـوكس والميكروب السبحى والعنقودى الذهبى. 
ووجـــ ان الكلورامفينــــل والسييروفلوكساسـين والانروفلوكساسـين وفلوموكـوين والجنتاميسـين

والنوروفلوكساسين اكثر المضادات الحيوية التى تؤثر على الستروباكتر فيروندى والميكروب العصوى القولونى والانتروباكتر والكلبسيلا اكستوكا والكلبسيلا اوزونى والكلبسيلانيمونى

السيبروفلوكساسين ودوكسى سيكلين والانروفلوكساسين والنروفلوكساسين اكثر المضادات الحيوية

التى تؤثر على مانهيمانيـا هيمولتيكـا والباستريلا ملتوسيدا ووالبـروتيس بنيبري والبروتس فـالجلريس والسودمونس ايروجونزا ويرسينيا انتروكولنيكا.

تم اجراء التحليل الكهروكيمائيى باستخدام اس دى اس ل 10 عينـات من ميكروب الكلبسيلا والميكروب القولونى واتضح انها تحتوى من 5-12 رابطة بعد صبغها بصبغة الكماسى الزرقاء والتى كان الوزن الجزيئى يتراوح من 7.218 الى 170.97 كيلو دالتون.

وقد وجد ان الوزن الجزيئى لميكروب القولونى E. coli O55 يتراوح من 7.2118 الى 134.55 كيلو دالتون امـا بالنسبة لميكروب E. coli Oيتراوح من 32.208 الى 134.55 كيلو دالتون E. وهى تتراوح من 23.311 الى 33. coli O115 وبالنسبة لميكروب 134.55 كيلو دالتون ولميكروب E. coli O125 تنزاوح من 8.4471 الى 131.24 كيل دالتون وبالنسبة لميكروب من 28.562 الى 118 كيلو دالتون وبالنسبة لميكروب E. coli O146 فهى تتراوح من 11.741 الى 1511.11 كيلو دالتون وبالنسبة ميكروب E. coli O166 فهى تتراوح من 21.137 الى 154.41. وعلى الجانب الاخر كان الوزن الجزيئى اكلبيسيلا اوكستوكا يتراوح من 15.859 الى 157.72 امسا بالنسبة لكلبسيلا نيمونى فالوزن الجزيئى يتراوح من 22.15 الى 167.66 واخيرا الوزن الجزيئى لكلبسيلا اوزونى فهى تتراوح من 38.016 الى 170.97 كيلو دالتون. 